\title{
Traditional and modern beekeeping practices in the center of Côte d'Ivoire: the case of the western part of Yamoussoukro
}

Chimène KAUDJHIS ASSI ${ }^{1}$, Gbouhoury Eric-Kevin BOLOU², Soumaïla SAVADOGO ${ }^{1}$ \& N'GUESSAN Koffi $^{1,3}$

${ }^{1}$ Botanical research unit, U.F.R. Biosciences, Felix Houphouet-Boigny University of Cocody, 22 BP 582 Abidjan

${ }^{2}$ Centre National de Floristique (CNF) of Félix Houphouët-Boigny University (Ivory Coast)

${ }^{3}$ Ake-Assi Botanical Institute of Andokoi (IBAAN)

Correspondent: 22 BP 582 Abidjan 22 (Ivory Coast); 22 BP 295 Abidjan 22 (Ivory Coast); Mobile: (225) 0839

44 19; E-mail: kaudjhischimene@yahoo.fr

DOI: 10.29322/IJSRP.10.11.2020.p10743

http://dx.doi.org/10.29322/IJSRP.10.11.2020.p10743 


\begin{abstract}
This study focuses on the evaluation of different beekeeping practices and the establishment of the beekeeping calendar in the rural western zone of Yamoussoukro in central Côte d'Ivoire. For this purpose, an ethnoapicultural survey based on a questionnaire was conducted among honey hunters and honey producers in this zone. The results reveal two types of beekeeping practices. The first is hunting or honey gathering which is a traditional practice, has a negative impact on the environment. The second is the modern practice of using modern hives to keep bees and using bee suits for honey collection. The modern practice is hygienic and has a positive impact on the environment. It also has a positive impact on the quality and quantity of honey. Annual honey production is on average 2.83 litres per natural hive and 12 litres per modern hive. The honey flow periods are from mid-August to mid-September and from mid-December to May. The dearth periods are from midSeptember to mid-December and from June to mid-August. Honey production is a significant potential source of income for the rural population. Lack of maintenance or poor maintenance of hives leads to bees deserting the hives. This work is a contribution to the knowledge of honey production in Côte d'Ivoire and to the promotion of modern practice, which is still not very widespread.
\end{abstract}

Index Terms- Beekeeping, traditional, modern, gathering, Côte d'Ivoire.

\title{
I. INTRODUCTION
}

Beekeeping is a science of raising and caring for bees to obtain honey, wax, pollen and royal jelly from their directed labor [1]. Beekeeping constitutes a positive externality for the environment and biodiversity [2]. Indeed, its main utility is the pollination by bees of the flowers of crops and market gardeners in general and particularly those of plants that require cross-pollination [3]. Initially based on harvesting natural production, beekeeping has gradually evolved towards the use of traditional hives and more recently of hives with so-called modern mobile frames [4]. Modern beekeeping is popularized in North Africa [5], the traditional practice is also widespread in sub-Saharan Africa in countries such as Senegal [6], Burkina Faso [7], Benin [8] and Cameroon [9]. Beekeeping production is mainly oriented towards honey in African countries and the quantity produced does not cover domestic demand [10]. Today, rural populations are interested in beekeeping, which appears to be one of the interesting alternatives for reducing poverty [4].

In Côte d'Ivoire, the work already carried out concerns the production, gathering and marketing of honey in Katiola [11], in Yamoussoukro [12]; the melliferous flora near the village of Soungassou [13] and to the east of the town of Yamoussoukro [14]. The major Ivorian honey producing areas are the center and the north. Indeed, the central region of Côte d'Ivoire, which is characterized by an abundant and very diverse flora, is favorable to beekeeping activity. In addition, in the Baoulé villages, in the center of the Ivory Coast, in addition to the natural vegetation, the large cocoa, coffee, rubber and papaya plantations constitute enormous honey potential. But to date, studies on the types of beekeeping practices common in Côte d'Ivoire and data on the different honey production areas are challenges for the Ivorian beekeeping sector. In this context, all the themes on the production of Ivorian honey are to be considered. This is why an assessment of the Ivorian beekeeping sector is a prerequisite for proposing effective methods of improving honey productivity in the country. The objective of this study is to assess the different beekeeping practices and to establish the beekeeping calendar for the Yamoussoukro district.

\section{MATERIALS AND METHODS}

\section{II.1. Presentation of the study environment}

Figure 1 shows the map locating the study area in Côte d'Ivoire. The District of Yamoussoukro is located in the center of the Ivory Coast, precisely between $06^{\circ} 7$ 'and $07^{\circ} 8^{\prime}$ ' North latitude and between $04^{\circ} 6$ 'and $05^{\circ} 6^{\prime}$ West longitude. It covers an area of 3,500 $\mathrm{km}^{2}$. The District of Yamoussoukro is an administrative entity that includes two municipalities: Yamoussoukro and Kossou [15]. It is bounded to the north by the department of Tiébisssou, to the south by the department of Oumé, to the east by the department of Dimbokro and to the west by the region of Marahoué with the departments of Sinfra and Bouaflé.

The study was carried out in the western part of Yamoussoukro, before the Marahoué region. The relief of the Yamoussoukro District is generally made up of plains and plateaus. Its soil rests on vast granite massifs of metamorphic and schistous rocks [16].

The District of Yamoussoukro belongs to the mesophilic sector of the Guinean domain [17]. It is subject to a subequatorial climate characterized by a rainy season from March to October and a dry season from November to February [18]. The vegetation of the District of Yamoussoukro is characterized by a mosaic of Guinean savannas and dense humid semi-deciduous forests [19]. 


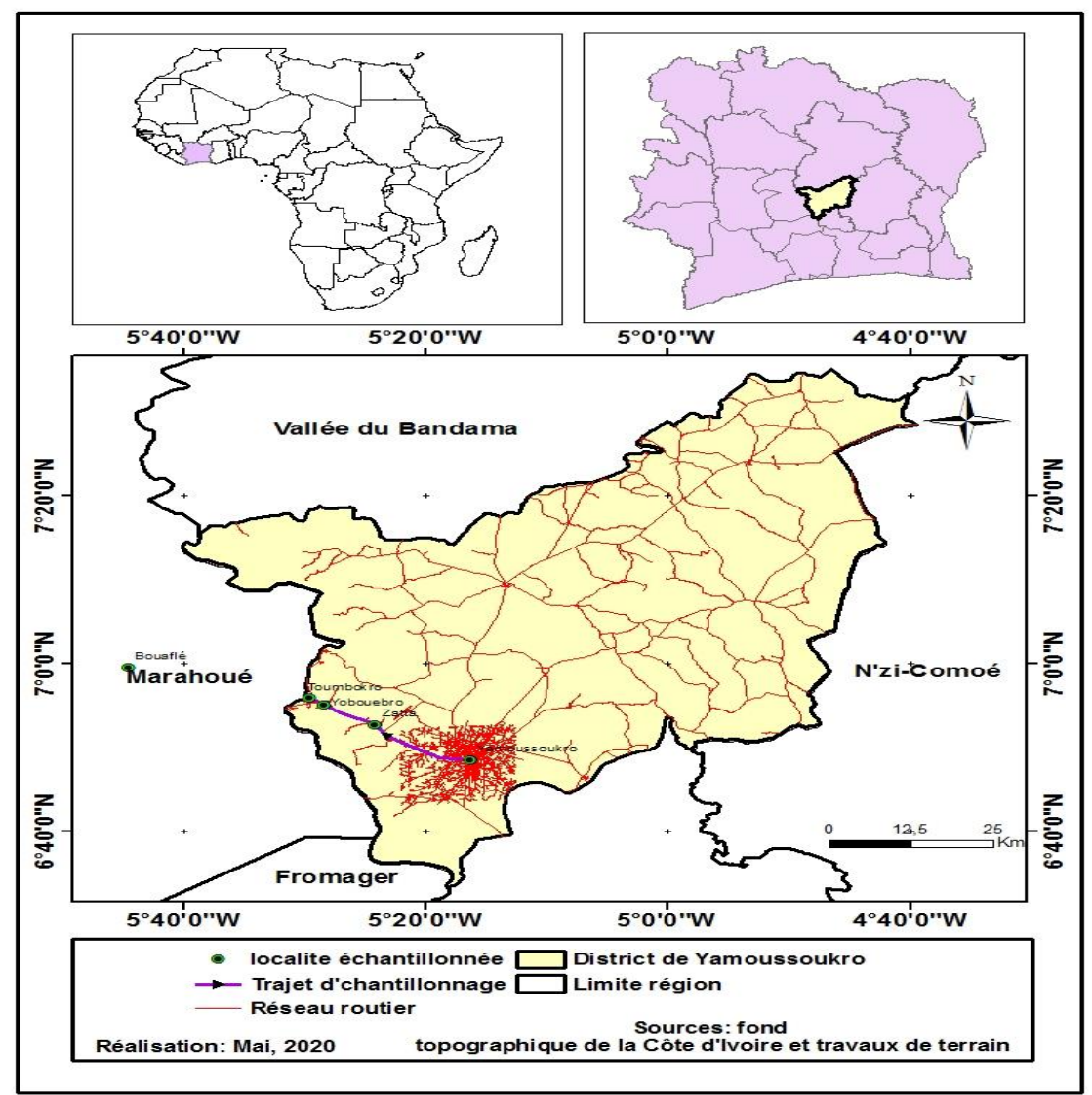

Figure 1. Map of the location of the study area in Ivory Coast

\section{II.2. Data gathering}

An ethno-beekeeping survey was carried out among honey producers in the villages around the Yamoussoukro Bouaflé axis, before the Marahoué region. The process consisted of two stages. The first consisted of conducting interviews with beekeepers in villages and camps, with questionnaires on the type of beekeeping practices, the quantity of honey produced, the impact of different beekeeping practices on the quality of honey and the environment, periods of honey and food shortages, and the health of the hives. The second step consisted of a direct field observation of the apiaries in the company of beekeepers with the aim of verifying certain information, in particular that relating to the environment of the apiary and the different honey harvesting methods.

The people surveyed are producers who harvested honey at least once over the period 2016-2018 and who marketed at least part of their production. The query was done at random. The approach used is the semistructured interview [20].

\section{II.3. Data analysis}

The data collected was coded for frequency analysis with Microsoft office Excel 2007 software and Sphinx plus2. For a given parameter, its frequency is the ratio expressed as a percentage of the number of honey producers who recognized this parameter by the total number of people surveyed [21].

We did a Multiple Correspondence Analysis (MCA) in order to perceive the relationships between the type of beekeepers and their harvesting equipment as well as their impacts on the environment and the quality of honey. Sphinx plus 2 made it possible to take into account the harvesting equipment used by beekeepers.

The increase or decrease in the amount of honey from one year to another is calculated by:

- the difference in quantity (dq) which is the subtraction of the smallest annual quantity (p) from the large annual quantity $(\mathrm{g})$

$$
d q=g-p
$$

- the proportion of quantity (pq) which is the ratio of the large annual quantity (g) to the small annual quantity (p) 


$$
p q=g / p
$$

The total quantity of honey produced in 3 years $(\mathrm{Qt})$ is obtained by adding the quantities of all beekeepers in 3 years $(\mathrm{Rp})$.

$$
Q t=\sum R p
$$

The months of honey flow and the months of famine made it possible to establish the beekeeping calendar for the study area.

\section{RESULTS}

The responses obtained were integrated into a crosstab to carry out an MCA in order to establish any relationships that may exist between the different factors. These are: the types of producers (traditional and modern), harvesting equipment (fire, machete, ax, water extracted from cassava paste, eggplant leaves, tobacco and water. simple) and the impact of different harvesting methods (negative or positive). A factor map presented in Figure 2 is obtained at the end of this analysis. The results of the map present two axes that contribute $79.99 \%$ to the establishment of the existing relationships between the different factors. Harvesting materials (tobacco, plain water, water extracted from cassava paste and eggplant leaves) contribute $91.67 \%$ to the formation of axis 1 while traditional producers, the impact (negative) and harvesting materials (fire, machete and ax) contribute $32.95 \%$ to the formation of axis 2. Axis 2 alone contributes $60 \%$. Figure 2 makes it possible to distinguish 2 groups:

\section{III.1. First group}

It is made up of traditional producers, their harvesting equipment and the impact of their harvesting method (Figure 2). The majority of these producers use fire, machetes, axes (figure 3) to be able to harvest their honey. However, some use the liquids extracted from cassava paste and eggplant leaves. Others take tobacco powder mixed with tap, well or creek water. Honey pickers brush themselves with these extracts to ward off bees. The water is used to spray the bees to make them immobile and facilitate harvesting with bare hands. Still others spray bees with tobacco to achieve the same effect. The honey is extracted by pressing the honeycombs by hand without sorting the capped honey. Furthermore, this ACM analysis shows that traditional beekeeping has a negative impact on the environment (Figure 4) and the quality of honey.

\section{III.2. Second group}

It includes all modern beekeepers, their harvesting equipment and the impact of their harvesting method (Figure 2). All modern beekeepers use a beekeeping suit (beekeeping outfit and gloves) and appropriate equipment (bee brush, smoker, knife and torch) for harvesting honey. Modern honey extraction is done by opening the lids of ripe honey and cakes by scraping the cells with a knife. Modern beekeeping technology has a positive impact on the environment and the quality of honey.

\section{III.3. Conservation}

All of the honey collectors surveyed store their honey in buckets and use the glass bottles as packaging material for sale. They also estimate the duration of consumption of their honey at 1 year.

Modern beekeepers store their honey in opaque 20 liter cans. They use the opaque half liter $(1 / 2 \mathrm{~L})$ and one liter $(1 \mathrm{~L})$ cans for sale. The latter believe that their honey remains edible for up to 3 years after harvest. 


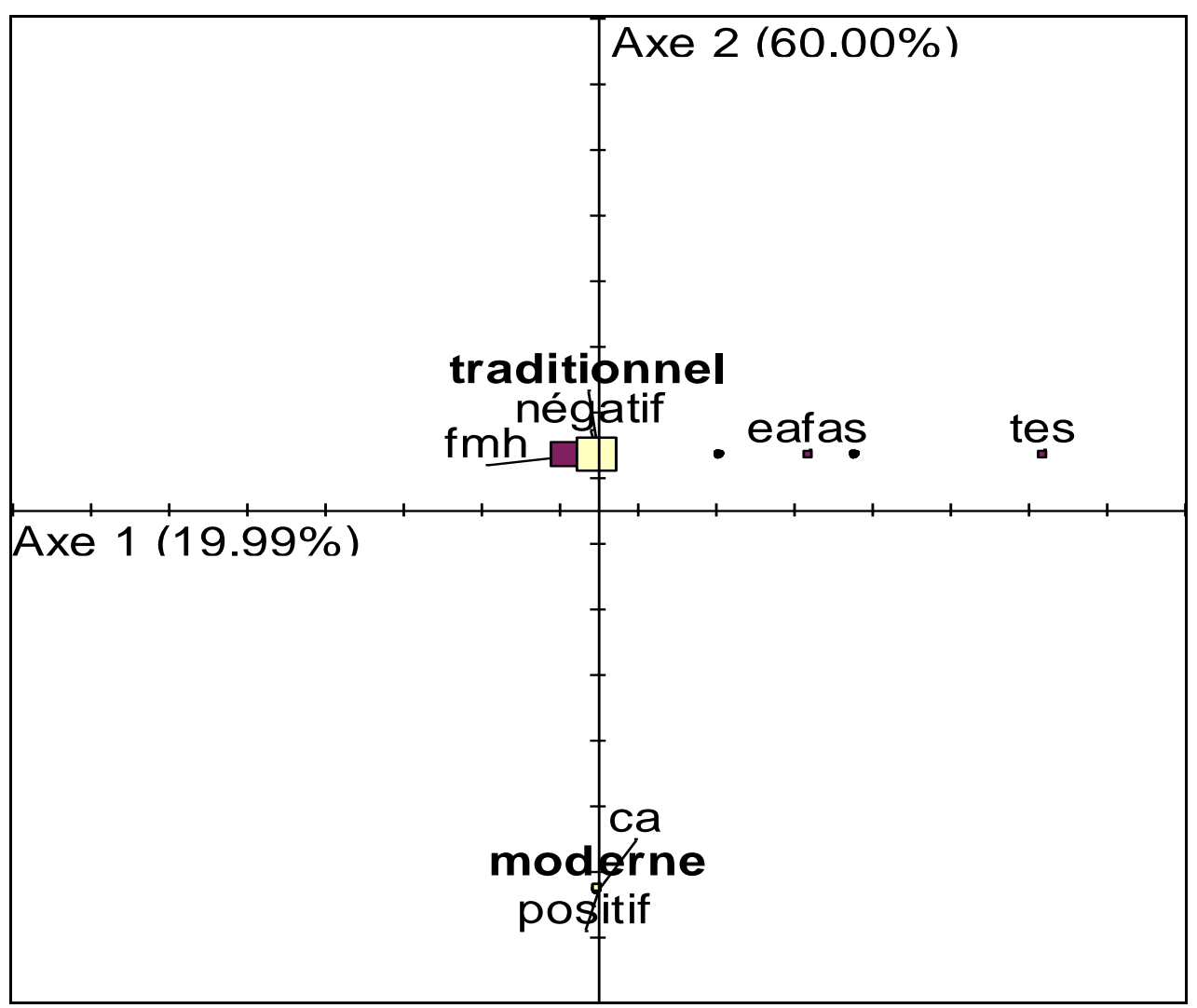

Figure 2. Relationship between types of beekeepers, harvesting equipment and the impact of their harvesting methods

fmh: fire, machete, ax; eafas: water extracted from cassava paste, eggplant leaves; tes: tobacco, water; ca: beekeeping combination 

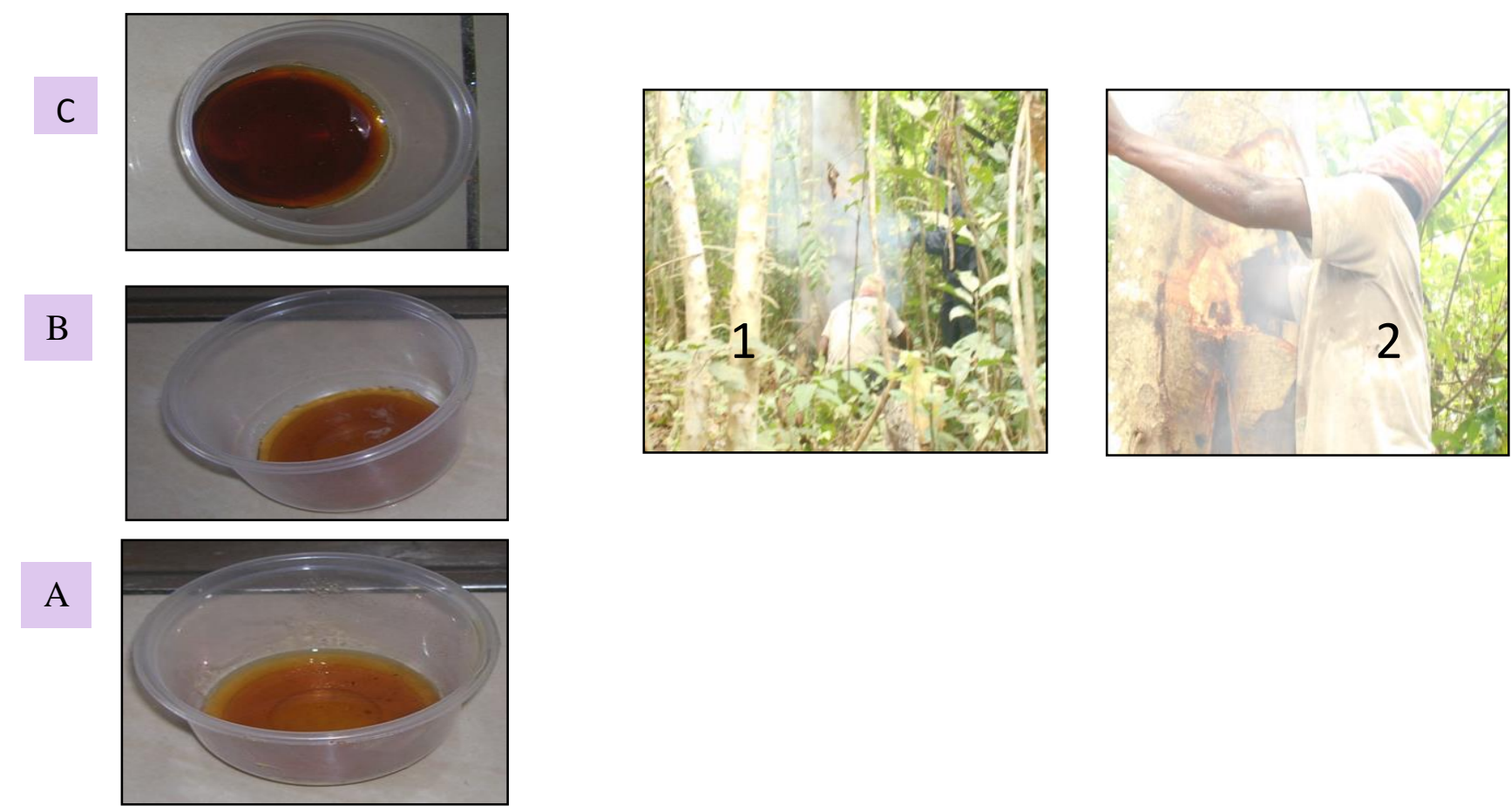

Figure 3. Traditional honey harvesting technique (1 and 2)

A: 3 month old honey, translucent; B: One year old golden brown honey; C: Brown or dark brown honey with a shelf life of 3 


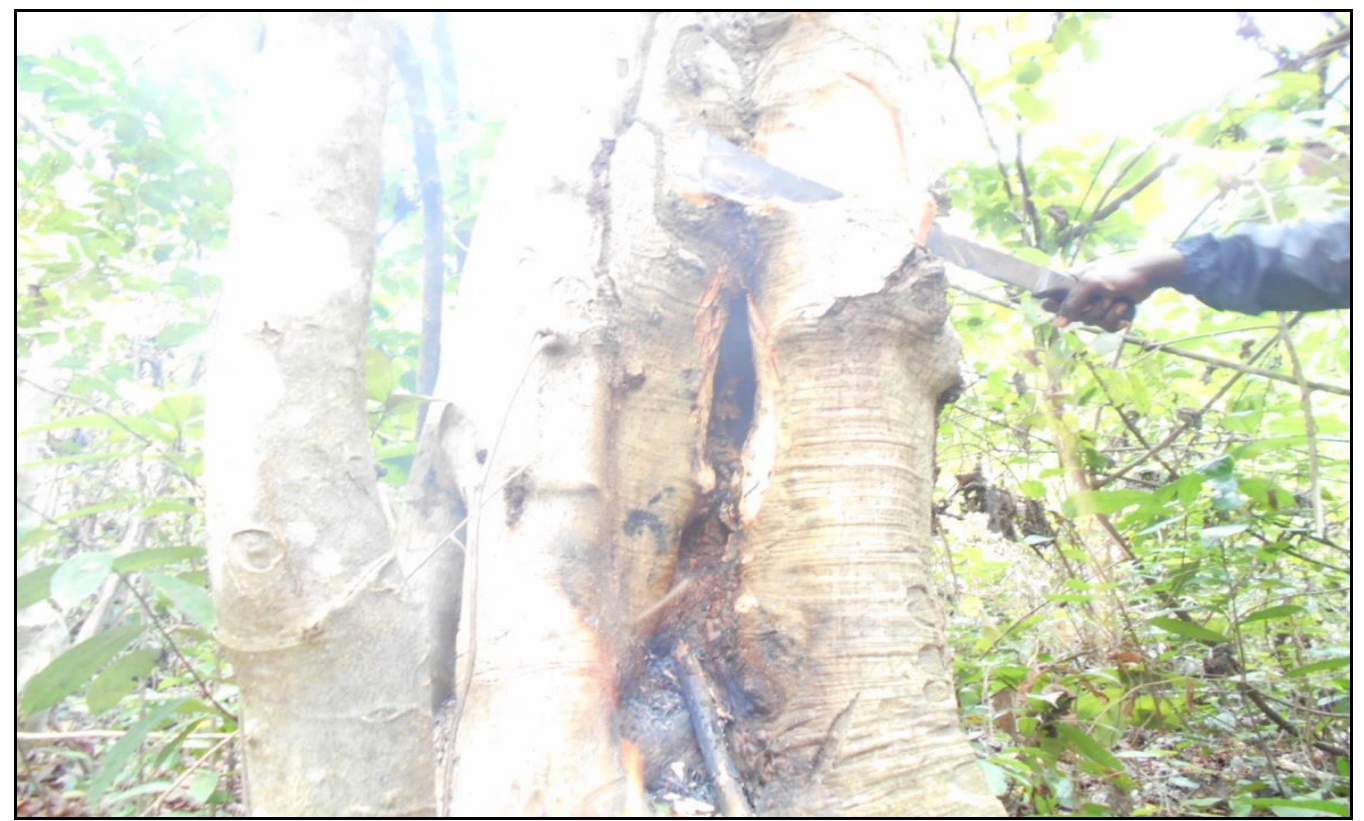

Figure 4. Impact of traditional honey harvesting in a natural beehive (hole in a living tree)

\section{III.4. Quantity of honey collected}

The quantity of honey produced during the period 2016-2018 is 2226 liters. The production varies according to the type of beekeeper, the type of hives and the years.

\section{III.4.1. Quantity from traditional production}

Traditional production varies depending on the year. In 2018, it was estimated at 493 liters. This quantity increased by 38 liters, i.e. $7.71 \%$ compared to 2017 (455 liters) and decreased by 17 liters, i.e. 3.45\% compared to 2016 (510 liters) (Table 1). In 2018, the yields per natural hive were highly variable, ranging from one liter of honey per hive to 12 liters with an average yield of 2.83 liters / natural hive.

\section{III.4.2. Quantity from modern beekeeping}

Modern honey production is growing over the years. Thus, in 2018 it was estimated at 457 liters. It increased by 245 liters or $53.62 \%$ compared to the year 2017 (212 liters) and by 358 liters or 78.34\% compared to the year 2016 (99 liters) (Table 2). In 2018, the average volume of honey produced by modern beekeepers is 76.17 liters. Yields per hive have been highly variable, ranging from 2 liters of honey per hive to around 16 liters with an average yield of 12 liters / modern hive.

Table 2.Variation in the quantity of honey from 2016 to 2018

\begin{tabular}{lllll}
\hline \multicolumn{5}{c}{ Quantity (liters) } \\
\hline \multirow{3}{*}{ Type of producers } & & In 2016 & In 2017 & In 2018 \\
& Traditional & 510 & 455 & 493 \\
& Modern & 99 & 212 & 457 \\
Total/year & & 609 & 667 & 950 \\
Total of 3 years & 2226 & & & \\
\hline
\end{tabular}

\section{III.5. Health status of hives}

Table 3 presents the factors causing the destruction and deterioration of the hives as well as the disappearance of the honey they contain. These anomalies influence the amount of honey produced in the hives. For honey hunters the main cause is the deserted hives. 
As for modern beekeepers, three causes have been cited: first, the hive can be deserted, this is the case for $70 \%$ of registered hives. Then, it can be attacked by black ants (20\%) and finally by false moth (10\%). Of all declared natural hives, $69.98 \%$ were attacked. $14.89 \%$ of modern hives have suffered damage.

Table 3: Different anomalies depending on the type of beekeeping

Producers and beehives

Anomalies

\begin{tabular}{cccc}
\hline & $\begin{array}{c}\text { Ants } \\
\text { attack }\end{array}$ & $\begin{array}{c}\text { Attack by false } \\
\text { moth }\end{array}$ & Deserted beehive \\
Number of producers concerned & 2 & 2 & 127 \\
Honey hunters & 0 & 2 & 121 \\
Modern beekeepers & 2 & 3 & 6 \\
Number of hives affected & 7 & 2 & 422 \\
Number of natural hives & 5 & 1 & 7 \\
\hline Number of modern beehives & 2 & 0 & 75 \\
\hline
\end{tabular}

\section{III.6. Beekeeping calendar}

The survey data enabled a beekeeping calendar to be established. It presents an alternation of periods of honey production called periods of honey flow and times of breaks also called periods of famine, during which there is no honey production. Two periods of honey flow were identified in our study area. They are interspersed by two periods of food shortages (figure 5). In other words, in the Yamoussoukro region, honey is harvested twice in a year. These seasonal beekeeping periods are distributed as follows: a small period of honey flow from mid-August to mid-September; a small period of famine from mid-September to mid-December; a great period of honey from mid-December to May and a great period of famine from June to mid-August.

Modern beekeepers rely on the weight of the hives to determine the periods of honey flow.

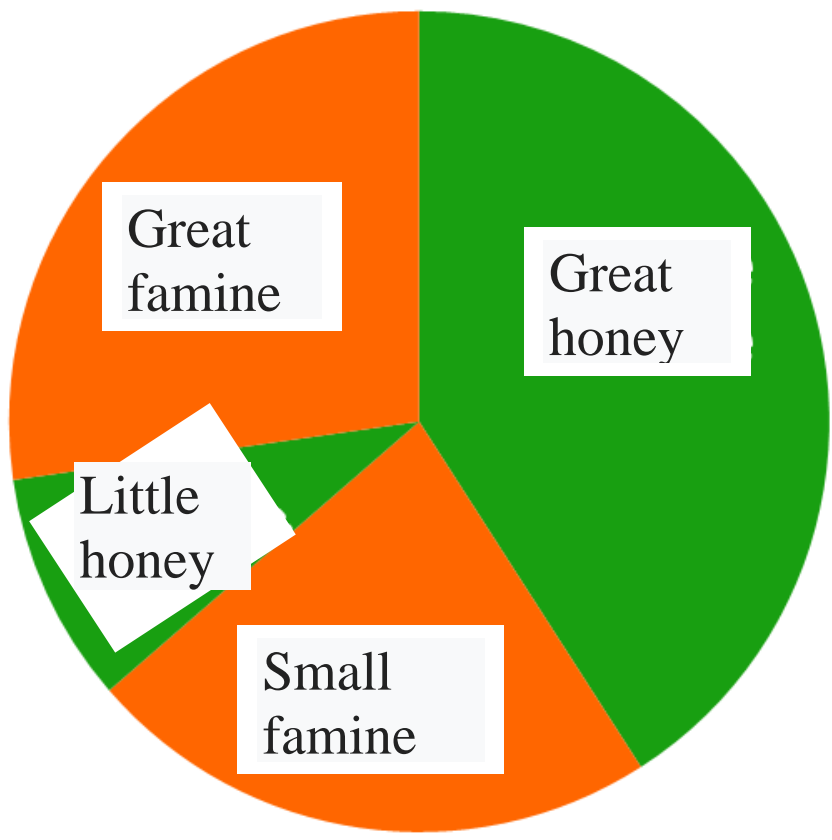

Figure 5. Beekeeping calendar of the study area 


\section{DISCUSSION}

\section{IV.1. Honey Harvesting Methods}

The traditional beekeeping equipment and techniques (fire, water, tree felling, etc.) used in the District of Yamoussoukro are similar to those described in Burkina by Nombré [22] in Rwanda, by Romet [23], in Mali by Van-Der-woerd [24], in Morocco by Damblon [25] and Schweitzer [26] and in Botswana by Kepalletswe [27]. The traditional harvest (use of fire, tobacco, water and liquid extracted from cassava paste, eggplant leaves) is harmful to the environment and causes massive death of bees either by burning, by drowning, either by poisoning. According to Kouassi et al. [11], traditional exploitation contributes to the degradation of the environment (cutting down trees to harvest honey, using bush fires, etc.). This very ancestral method should no longer be practiced. Indeed, from 16 million hectares at the end of the 19th century, the area of dense humid forests is estimated at 2.5 million ha at the end of the 20 th century, and about 1.385 million ha at the beginning of the 21 st century, with a deforestation rate of $1.86 \%$ per year [28]. This disorganized deforestation situation, which is dragging Côte d'Ivoire into an ecological impasse, shows that the country must supervise the wild harvest of honey.

The honey collected by honey hunters contains a lot of animal and plant debris. After the fire has passed, this honey is colloquially called "burnt honey". It mixes with debris from tree trunks and the remains of animals that visit natural hives. According to Nombré et al. [29], in addition to the earliness of the harvests, the quality of honey is still affected by the equipment used for collecting, extracting and storing honey. The traditional method results in a honey that does not escape the presence of plant debris (ashes) and animals (broods, dead bees). Such honey, even after skimming, loses some of its therapeutic and nutritional properties [30]. The presence of animal proteins (dead bees and broods) and plant debris in honey affects its longevity. Therefore, the duration of consumption of honey by hunters and gatherers does not exceed 1 year.

On the other hand, modern practice which is more respectful of the environment should be encouraged. Cakes of ripe honey, carefully sorted and stored in opaque containers (canaries, gourds and wooden containers), retain all their therapeutic and nutritional properties for a long time [22]. Honey harvested by the modern method can remain edible for up to 3 years. This result is comparable to that of Swiss beekeepers who estimate the minimum shelf life of honey, at 3 years, when the honey is in good conditions [31].

Modern beekeepers, caring about bee life and their environment, use harvesting techniques that protect bees. In addition, they know that bees feed on their honey and stock up for times of famine due to lack of nectar. As a result, beekeepers leave some of the honey in the hive to ensure the survival of the bees. According to Tsafack et al. [32], the modern techniques used make it possible to make the apiary more profitable in order to only have strong colonies; in addition, the honey collected is clean and of excellent quality.

\section{IV.2. Quantity of honey collected}

The quantity of honey produced by traditional operators varies from year to year. To explain this, traditional producers invoke the lack of time to locate natural hives. The time allocated to traditional beekeeping is therefore almost negligible [11] ; [12], because it is an activity that is done in parallel with their field work. The average volume of honey collected per natural hive is 2.83 liters. This low rate could be explained by the fact that natural hives are not maintained. They can be attacked by animals that love honey. To this end, [5] argues that the habitat of wild bees is rudimentary and exposed to the elements.

The amount of honey harvested by modern beekeepers is high and gradually increases over the years. Unlike traditional producers, modern beekeepers pay enough attention to beekeeping. The average volume of honey collected per modern beehive is 12 liters. This volume indicates a better yield compared to that of the production from the collection of honey. This average honey yield per modern hive is comparable to that of Manigri in Benin which is $11.2 \pm 3.7$ liters [21] and of the western highlands of Cameroon which is 10 liters [4]. The average annual volume of honey harvested (76.17 liters) by modern beekeepers in Yamoussoukro is lower than that obtained in beekeeping farms in North-West Cameroon which is 112.68 liters [32], and in the commune of Cobly in the northwest of Benin with $148.57 \pm 77.01$ liters [8]. Compared to the quantities of honey from modern producers in other countries, the low quantity of honey from modern beehives in the study area is explained by the fact that modern beekeeping is very recent in the region. Indeed, until 2014, the region had only one modern beekeeper.

\section{IV.3. Health status of the hive}

Black ants and false moth attack beehives because they are honey lovers. They attack the bees when the honey is ripe in the hive. False moth is a disease that attacks bee broods in the hive. The abandonment of hives by bees or deserted hives was the most reported by producers. The fragility of modern beehives is linked to the material used for their making: "white wood" or "red wood". The first being lighter and less resistant to insects than the second. Modern beekeepers use wax to brush their hives to preserve them from outside bodies. When this step is not done properly, the life span of the hive is reduced because it is exposed to ants. Modern beehives can also be attacked by other diseases. Kabar et al. [33] identified false moth, mycosis, calcified brood, nosemosis, attack by black ants as responsible for the destruction of the hive. 
Unlike natural hives, the percentage of modern beehives attacked is low. This could be explained by their interview [34]. Natural hives are the most affected by the anomalies. According to Fred [34], natural beehives are the most exposed to the elements. These natural habitats of wild bee colonies, qualified as poorly compliant [35] are vulnerable. They can therefore be attacked by honeyloving insects and bee enemies.

The reported desertion of natural hives could be due to the lack of training of honey collectors. Not keeping track of their hive, they cannot prevent these attacks which reach the hive. Then, climate change by disrupting the phenology of plant species, may have led to the displacement of bee colonies.

\section{IV.4. Beekeeping calendar}

The beekeeping calendar is made up of a succession of periods of food shortages and periods of honey. It gives indications on the favorable periods for rearing honey bees and the availability of honey in the region. It will allow anyone wishing to do beekeeping in the Yamoussoukro region to know the favorable periods for honey production. 8.5 months of honey flow were observed in the area. This result is comparable to that found by [22]. The latter capitalized on 7 months of honey flow in the Garango region in Burkina Faso. During the honey flow, beekeepers refer to the weights of the hives to choose the harvest time. In fact, the hives become heavier because of the products made by the bees: honey, wax and propolis. Indeed, according to Lavie [36], the weight of the hive is low during the period of scarcity, but high during the period of honey flow.

\section{CONCLUSION}

Observations made with honey producers in Yamoussoukro made it possible to identify two beekeeping practices: the very old traditional method and the recently introduced modern method. The first uses a material which, by negatively impacting the environment as well as the quality of honey, destroys bee colonies and their habitats, thus threatening ecosystems and biodiversity. The second is the most environmentally friendly and produces better quality honey in better quantities. In fact, the use of appropriate beekeeping techniques allows the proliferation of bee populations, which will help to perfect the pollination of the flowers in the region. The lack of maintenance or the bad maintenance of the hives leads to the deserting of the hives by the bees. The honey production periods run from mid-August to mid-September and from mid-December to May.

It emerges from this study that the beekeeping sector in Yamoussoukro is not structured by official rules. The vegetation of the area constituting an important potential for beekeeping activities, the Ivorian beekeeping field requires the supervision of actors in order to improve the quality and quantity of honey produced while preserving the environment.

\section{REFERENCES}

[1] Mr. Biri. The bee ledger. Modern beekeeping course (2003). In Nair S.,. Identification of meliferous plants and physicochemical analyzes of Algerian honeys. Thesis, University of Mascara, 191p. (2014).

[2] B.J.D. Dushimimana. Report on the Study of Beekeepers around the Volcanoes National Park. UNDP report, Rwanda, 17 p.(2007).

[3] L. Leven, .W.J Boot, M. Mutsaers, P. Segeren \& H. Velthuis. Beekeeping in the tropics. Agrodok Series No. 32, NECTAR, 95 p. (2005)

[4] J. Tchoumboue, I.R. Tchouama, J.Y. Pinta \& M.N. Njia. Socio-economic and technical characteristics of beekeeping in the highlands of western Cameroon. Tropicultura, 19 (3), 141-146 p. (2001).

[5] M.H. Hussein. Beekeeping in Africa. Apiacta., 1: 34 - 48p. (2001). Available online at http://www.apimondiafoundation.org/pdf

[6] P.N. Dieye, A. Faye, M. Seydi, S.A. Cissé. Peri-urban dairy production and improvement of the incomes of small producers in rural areas in Senegal. Cahiers Agricultures, 11, 251-257. (2002).

[7] Number. Beekeeping in Burkina Faso. Communication, p. 8. (2011). Available online at http://www.apiservices.com/articles/fr/guenange_nombre_issa.pdf

[8] T.B. Ahouandjinou, H. Yedomonhan, C.A. Adomou, G.M. Tossou. \& A. Akoegninou. Technical characteristics and socio-economic importance of beekeeping in North-West Benin: case of the municipality of Cobly. Int. J. Biol. Chem. Sci. 10 (3): 1350-1369. (2016).

[9] M.A.S. Tsafack., A.G. Muluh, F. Kamajou, I. Verina \& B.M. Vabi. Comparative study of the profitability of two types of beekeeping in Northwest Cameroon. Tropicultura, 29 (1): 3-7. (2011).

[10] FAO. Documentary and statistical production on cotton, oil palm, milk, beekeeping, poultry farming and rural credit in West and Central Africa. CMA / AOC, Technical note on the beekeeping sector, 14p. (2005).

[11] D.F. Kouassi., D. Ouattara., S. Coulibaly \& K.E. N'Guessan. The collection, production and marketing of honey in the Department of Katiola (Center-Nord, Cote d'Ivoire) Int. J. Biol. Chem. Sci. 12, 2212 - 2225. (2018).

[12] S. Savadogo, K.C. Assi, K. N'guessan. Note on the place of beekeeping in Baoulé society in Côte d'Ivoire: case of two villages in the District of Yamoussoukro. Geo-Eco-Trop, 42, 1: 199-206. (2018).

[13] S. Coulibaly, D. Ouattara \& K. Kamanzi. Diversity and configuration of the woody flora around an apiary in the forest-savanna transition zone of the Ivory Coast. Journal of Applied Biosciences, 68: 5374-5393. (2013).

[14] B.M. Iritié, E.N. Wandan, A. Paraiso, A. Fantodji \& L. Gbomene. Identification of honey plants in the agroforestry zone of the Higher Agronomic School of Yamoussoukro (Ivory Coast), 15p. (2014).

[15] RGPH. Global Results. 22p. Available on the site: file: /// I: /yamoussoukro/RGPH2014D.pdf. (2014) [05-03-2017]

[16] J.L. Kouassi. Monitoring of the dynamics of land use using satellite imagery and geographic information systems: case of the regional directorate of water and forests of Yamoussoukro (Ivory Coast). Thesis ENSA / ESA 43rd Promotion. Yamoussoukro, Ivory Coast, 51p. (2014). 


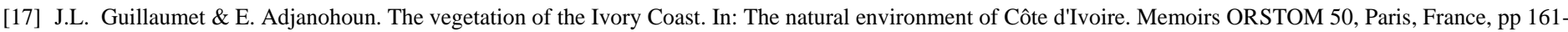
263. (1971).

[18] M. Eldin. The climate of the Ivory Coast. In: The natural environment of Côte d'Ivoire. Memoirs ORSTOM, 50, Paris, France, 50: 72 - 108. (1971).

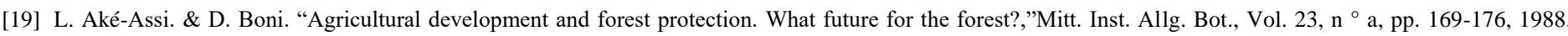
(1998).

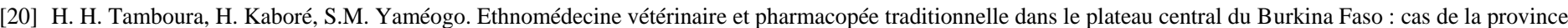
du Passoré. Biotechnol. Agron. Soc. Environ., 2(3): 181-191. (1998).

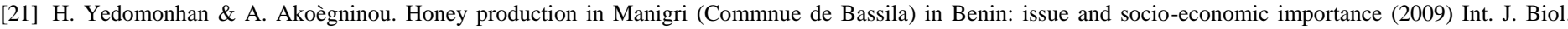
Chem. Sci., 3 (1): 125-134. (2009).

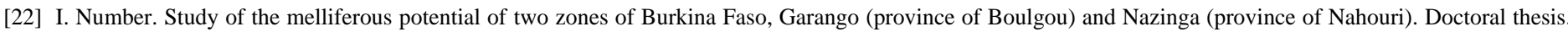
3rd cycle, University of Ouagadougou. Burkina Faso, 186p. (2003).

[23] A. Romet. The adansonii bee in the highlands of western Cameroon. The Bee of France and the beekeeper, 859: 257-261. (2000).

[24] M. Van-Der-Woerd. Beekeeping in the tropics. L'Abeille de France et l'Apiculture, 827: 267-272. (1997).

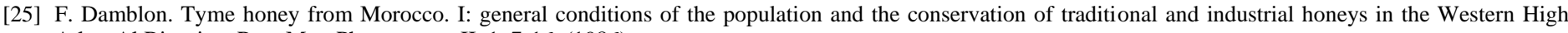
Atlas. Al Biruniya, Rev. Mar. Pharm, tome II, 1, 7-16. (1986).

[26] P. Schweitzer. Beekeeping in Morocco. L'Apiculture de France et l'Apiculture, 878, 93-100. (2002).

[27] Kepalletswe. K. (1997). Beekeepinp in Botswana, 4th edition, 76 p.

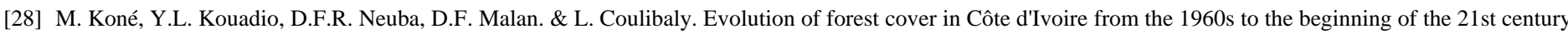
International Journal of Innovation and Applied Studies Vol. 7 No. 2, pp. 782-794. (2014).

[29] I. Number, M. Sawadogo, I.J. Boussim \& S. Guinko. Beeking in Burkina Faso.Bees for Developpement Journal, 65, 9. (2002).

[30] P. Schweitzer. Beekeeping in Morocco. L'Apiculture de France et l'Apiculture, 878, 93-100. (2002).

[31] P. Gallmann. Minimum shelf life, now also for honey. Beekeeping research center. Agroscope Liebefeld-Posieux (ALP) research station, 4p. (2007).

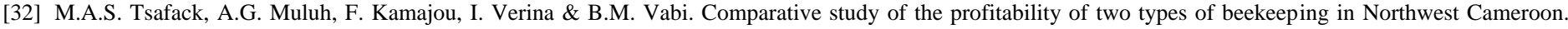
Tropicultura, 29 (1): 3-7. (2011).

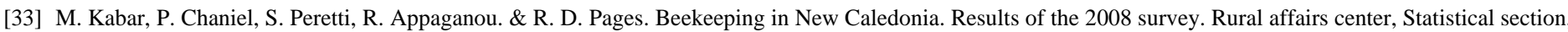
34p. (2009).

[34] M. Fred. Getting started in beekeeping. Granada, Spain. Second corrected version, 22 p. (2001).

[35] D. Betayene. Beginning in beekeeping. Center for Environment and Development (CED), Yaoundé-CAMEROUN PO Box: 3430,44 p. (2008).

\section{AUTHORS}

First Author - Chimène KAUDJHIS ASSI, Teacher-researcher, Botanical research unit, U.F.R. Biosciences, Felix HouphouetBoigny University of Cocody, kaudjhischimene@yahoo.fr.

Second Author - Gbouhoury Eric-Kevin BOLOU, Researcher, Centre National de Floristique (CNF) of Félix Houphouët-Boigny

University (Ivory Coast), bgeric3@yahoo.fr.

Third Author - Soumaïla SAVADOGO, Student, Botanical research unit, U.F.R. Biosciences, Felix Houphouet-Boigny University of Cocody, savadogosoumaila53@yahoo.fr

Four Author - N'GUESSAN Koffi, Teacher-researcher, Botanical research unit, U.F.R. Biosciences, Felix Houphouet-Boigny University of Cocody, Ake-Assi Botanical Institute of Andokoi (IBAAN), nguessankoffifr@yahoo.fr.

\section{Correspondence Author - Chimène KAUDJHIS ASSI, kaudjhischimene@yahoo.fr, $\quad(+225) \quad 08 \quad 39 \quad 44 \quad 19$.}

